\title{
Factor model of investment climate monitoring in chaotically structured economy
}

\author{
Maria Vakulich \\ Department of International Finance and Banking, Alfred Nobel University, Dnipropetrovsk, Ukraine
}

Email address:

mariavakulich@mail.ru

\section{To cite this article:}

Maria Vakulich. Factor Model of Investment Climate Monitoring in Chaotically Structured Economy. Journal of Finance and Accounting. Special Issue: Synergy of Accounting, Finance and Management in Chaotic Environment. Vol. 2, No. 6-1, 2014, pp. 31-36. doi: 10.11648/j.jfa.s.2014020601.15

\begin{abstract}
Methodical approaches to the investment climate assessment, which are used by leading national agencies and international organizations for ranking countries have been considered in this article, the need for indexes analysis of Ukrainian investment climate in order to identify the further ways of institutional environment improvement for attracting foreign investments improving the efficiency of the control system of the Ukraine's economy investment climate has also been identified. Monitoring of Ukraine's economy investment climate, presented by factor model, has been proposed. Implementation of monitoring systems will help to ensure the comprehensive nature of its functioning in Ukraine's economy.
\end{abstract}

Keywords: Investment Climate, Monitoring, Investment Position

\section{Introduction}

Under conditions of globalization, the economic development of any country is closely linked to increasing its investment attractiveness for foreign investors. When making an investment decision about the production location in one or another country, a foreign investor assesses its potential investment market first. The definition of investment attractiveness of the country refers to the number of complex tasks, which are based on different approaches.

An important factor in attracting international investment is the country's image in the international arena, its position in the leading rating ranking, the experience of other investors doing business in the country and so on. The growth of foreign investments leads to increasing the level of economic development of the country-recipient, therefore, for investments revival in Ukraine it is necessary to review all internal and external factors, which form, in the aggregate, investment environment of the country and directly or indirectly affect the willingness of foreign investors to invest their capital in it. First the definition of the modern economy as chaotic structured was proposed in 2010 Kuznetsova S. She noticed that the modern features of development of world and economy, which openness, instability, dynamic and independent organization, is inherent for, stipulate the necessity of ground of new scientific approaches to forming of informative resource [1, p. 151].

The effective functioning of the investment policy in Ukraine in modern conditions of instability and chaotic economic environment it is essential to improve all organizational and economic mechanism of investment, including the development of a comprehensive and effective management concept of the investment climate. Therefore, it is necessary to investigate how the investment climate inherent in Ukraine, to identify key issues, and to consider areas for improvement.

\section{Model}

Increasing of imbalances and inequities of global business processes, differentiation in levels of states development, due to increase in equivalency of interstate exchange, intended restrictions by state and technological leaders of the diffusion of technological achievements and increased competition for factors of production and the world markets distribution are objective realities of today. Achievements and gaps of globalization differentially extrapolated on a national basis depending on the level of competitiveness and sustainability of national economies is determined by the efficiency of public management.

The problem of achieving sustainable growth of Ukraine's economy requires investment processes activation, the 
transition from the current control and regulation on long-term strategic planning. However, strategies development of individual kinds and activities do not ensure resources, time, and priorities balance. Therefore, it is necessary to develop a complex mechanism of investment climate regulation in Ukraine's economy.

The main condition for further innovative development of Ukraine's economy is searching for new ways of attracting investments for Ukraine's future economic development. The issue of investment image and investment attractiveness of Ukrainian economy formation was considered in the works of A. Gavrilyuk [2, p. 99], the formation of the concept of improving the Ukraine's investment climate was analyzed by A. Malyutin [3, p. 41], an innovative paradigm of activities management was analyzed by V. Rossoha [4, p. 61], the rating of Ukraine's economy in terms of investment attractiveness was considered by N. Marchenko [5, p. 94 - 100].

Climate change leads to a redistribution of investment flows in the global environment and determines the activity of investors in different states. Therefore, the position of the state in world ratings of investment climate assessment serves as the basis for investment processes and determines the level of foreign investment in the economy.

However, despite the large number of original and meaningful works of both foreign and domestic scientists studied the issue, it is necessary to identify that there are virtually no basic research on the problems of analysis of investment climate in Ukraine's economy. Thus, a number of issues associated with the analysis of the investment climate of Ukraine's economy and its prospects remain unresolved, in particular in the scientific literature there are varieties of points of view on the specific content of the information base of such a research.

In terms of internationalization of the world economy and the liberalization of capital flows the risks of uncontrolled trans boundary movement of investment capital are constantly increasing, which raises questions about the creation of means of state investment policy - monitoring of the investment climate that allows Ukraine to regulate not only the process of combating the legalization of income, but also to carry out macroeconomic impact on the economy in the area of state regulation and transparency. Relevant is the selection criteria for the formation mechanism of coordination of activity of subjects of monitoring that will allow you to create the optimal national model monitoring in Ukraine.

Monitoring is becoming an effective tool of investment policy subject to timely entry of quality information to the participants in the investment process. In case of uncertainty and variability of the investment performance, developed monitoring system should be adjusted by changing investment environment. The problem of monitoring is the formation of a methodological strategy, which is based on the economic analysis of statistical indicators. The informational basis of monitoring studies is the base of systematic indicators that come from different sources: indicators of activity of subjects of investment activity (investment resources, changing investment patterns, investment efficiency); informational resources concerning the condition of the legal support of the investment process.

That is why, at the present stage of Ukrainian economy development as for increasing the investment activity, issues concerning the development of a system of indicators characterizing the state of the investment climate at the macro at meso- and micro levels of the economy are becoming urgent. Therefore, the assessment of the investment climate should be comprehensive, methodical base should be multifaceted, and monitoring should be a complex of several groups of indicators.

In modern conditions of economic development that is characterized by instability, rate of change, repeatedness of crisis developments and the increased value of information in the process of management, it is necessary to have information canters, which would systematize information resources and form the database for the participants of the investment process. The availability of such centers require special knowledge and skills, professional training, and the creation of complex automated systems of informational and analytical support of making investment management decisions on the basis of modern information and computer technologies. In particular, monitoring the Ukraine's investment climate can be done by creating a Center on monitoring investment processes - it is a scientific institution which purpose is the investment climate analysis and preparation the recommendations on the improvement of its organization. The most important is to conduct a comprehensive assessment of the investment climate of Ukraine's economy (based on monitoring data) by forming an integral index, combining quantitative and qualitative results on groups of factors. Within the scope of this we will analyze the state of the components of the investment climate of the national economy according to economic indices. The most common indexes in different countries of the world are (Table. 1).

Table 1. The most common indexes of the investment climate in different countries of the world

\begin{tabular}{ll}
\hline State & Economic indices \\
\hline & Dow Jones Industrial Average, Dow Jones \\
The USA & Transportation Average, AMEX Composite, NASDAQ \\
& 100, NYSE Composite, Standard \& Poor's Composite \\
& 500 Index, Value Line Composite, FTSE, STI \\
France & CAC-40, CAC General \\
Germany & DAX 30, Xetra DAX, DAX 100, CDAX \\
Great Britain & FT-SE 30 Share Index, FT-SE 100 \\
Japan & Nikkei, Topix, JPN \\
Canada & TSE 300 \\
Hong Kong & Hang Seng Index \\
\hline
\end{tabular}

According to Kuznetsova S., who has founded and actively investigating a new direction in the world of science: the synergetic development of finance systems, accounting and business, which chaotically structured in global economy): «The modern world economy is characterized by paying greater attention to the effectiveness of doing business in conditions of financial markets globalization and the capital movements liberalization» [6, p. 82]. So, one of the main tasks, which modern society face is the creation of necessary and 
favorable conditions for economic growth intensification, improving the population's quality of life. The achievement of the given tasks can be implemented by attracting investments. The volume and pace of investment growth are indicators of the investment climate. Investors choosing the state for capital investment, guided by certain characteristics: for example, investment potential, level of risk. There is no comprehensive model for monitoring the investment climate in Ukraine. The main issue is the creation of such a model.

At present, there are a lot of systems of country's investment climate assessments. So, the most common are the ratings of Institutional Investor, Euromoney and Business Environment Risk Index (BERI). Institutional Investor focuses primarily on the creditworthiness of countries, Euromoney - on study of three groups of indicators: market, credit and political and economic groups. A more extended structure for the rating formation has the BERI system.

There are also national investment climate rankings, which are periodically published by the leading economic magazines (Fortune, The Economist, respected expert agencies (Moody's, Standart and Poor, IBCA). Among various international methods of investment attractiveness evaluation, it should be mentioned the assessment of the World Bank Group, the World Economic Forum (WEF), Heritage Foundation / Wall Street Journal, Transparency International etc. [7, 8].

A comprehensive assessment of the investment climate in various methods based on the analysis of several components of the investment climate, but not a comprehensive assessment of its condition at the macroeconomic level. Thus, methods of the international assessment of the investment climate have significant discrepancies, however, a large number of methods of ranking allows the investor to obtain comprehensive information regarding all the aspects of the investment climate in Ukraine's economy and the systematic comparative analysis of the effectiveness of national competitive environment. Transparency of information regarding methods to rank most of the criteria gives the right to influence the future performance through reform, primarily in weak rating positions. Basing on international rating assessments and indicators of economic indices, it was made a conclusion that at the present stage there is no methodology that would fully satisfy the interests of investors. There are only a few indicators of the investment climate, but there is no established comprehensive model for the assessment of the investment climate. This situation is caused by the low level of economic development of Ukraine, because publications in various ratings and information surveys confirm that the vast majority of ratings and indexes aim to identify investment potential based on the level of economic development of a region, not comprehensively throughout the state, and conduct only the evaluation of investment attractiveness, which is the part of investment climate, but not an integrated monitoring of the investment climate in the economy of the state. The analysis of foreign methods of investment climate assessment leads to the conclusion that the index creation according to the investment climate criterion should be based on a systematic analysis of the situation and a comprehensive search for possible ways of its further development, factors identification affecting the adoption of investor management decisions and subsequent implementation of investment projects.

Ukraine's investment climate is influenced by the complex interaction of factors of political, economic, legal, social, technical and environmental nature. A plurality of various factors affecting the investment climate, the contradictions between them and the need to consider several different models of monitoring the investment climate and led to the formation of two models of monitoring. In terms of the chaotic state's economy, the diversity and the increase in potential solutions, forming a single option is impossible.. In this situation, it is vital to use of a comprehensive assessment methodology based on the application of the methodology for the calculation of indicators. Monitoring the investment climate in the economy of Ukraine is determined in the ranking, as a set of factors that shape the investment climate of the national economy. These factors are an active background for investment projects in the priority sectors of Ukraine's economy. Thus, the investment climate of Ukraine's economy consists of several factors, each of which can be estimated by adjusting for individual proxy variables.

In the proposed factorial model of monitoring the investment climate in Ukraine's economy uses six different factors: political factors, legal factors, economic factors, social factors, technological factors, environmental factors. To assess each of the six factors it was created the set of different number of parameters (proxy variables) to determine the value of specific weight in the overall index for each of the factors.

Theoretical and methodological basis for the construction of the proposed factor models is the use of methods of theoretical generalization and comparison, for disclosure the investment climate as an economic category. For determining the regularities of the development of the modern system of management of investment climate the dialectical method is widely used. In the analysis and systematization of the functions of public authorities in the management of the investment climate in Ukraine's economy used a systematic structural analysis. For studying, grouping and display the empirical data, the elimination the influence of random factors in the analysis of investment funds flows in the national economy, to identify tools for the analysis of the investment climate of Ukraine's economy by regions and components diagnose the state management of investment climate by sectors of the national economy, methods of statistical and graphical analysis are used. In determining the nature of the investment climate, differences of this concept from other monographic method is used; when determining the effectiveness of the investment climate management analytical method is used; at the analysis of functions of public authorities - regulatory method is used.

Informational base of research is theoretical, scientific and practical works of domestic and foreign scientists on the problems of managing the investment climate, regulatory and legal acts that directly or indirectly regulate investment processes in Ukraine, analytical materials of the Ministry of foreign economic relations and trade of Ukraine, Ministry of 
Finance of Ukraine, the National Agency of Ukraine for development and European integration, international cooperation Agency and investment, statistics of the State statistics Committee of Ukraine, electronic Internet resources for management of the investment climate in Ukraine's economy.

Investment climate includes the objective possibilities of the country (investment potential), the institutional environment and conditions for the investor's activity (investment risk) and allows us to compare these figures. In a situation where the investment attractiveness of the investment exceeds the risk it is advisable to talk about the formation of investment attractiveness in the state. So, the factors which are the basis for model generation monitoring the investment climate in Ukraine's economy have been assigned the following scales: political factors - the proportion of the overall index - 0,23; economic factors - 0,22 ; legal factors - 0,33 ; social factors - 0,1 ; technical factors - 0,1 ; environmental factors $-0,02$.

Each of these macroeconomic factors shaping the investment climate in the national economy is analyzing in way that is more detailed and assigned scores from 0 to 10 based on the rating and expertise and is determined by its specific weight and the total integral indicator.

Factors of the investment climate formation in the national economy are an active background for investment projects in the priority sectors of Ukraine's economy.

Based on the identified factors formed the General integral indicator (In), which is calculated by the formula:

$$
\text { In }=\sum(x i \times y i)
$$

where, $x i$ is the estimation of the factor that affects the investment climate; yi is the weight factor in the integral indicator of the investment climate.

$$
\mathrm{xi}=\sum(\mathrm{zi} \times \mathrm{pi})
$$

where, zi is the score in terms of factors that affect the investment climate; pi is the share component in the factor.

Using the calculated indicators of the investment climate in the economy of Ukraine by the factor model, you can define the integral indicator of the investment climate of Ukraine. This indicator allows you to determine the level of favorable investment climate to invest in the position of making the investment and maximum profit.

The problem of achieving sustainable growth of Ukraine's economy requires the investment processes activation, the transition from the current control and regulation on long-term strategic planning. The subjects of investment activity must be able to monitor continuously the state of the investment climate in Ukraine's economy and to compare it with other countries. The authors propose the following ranking General of the integral indicator of the investment climate in the economy of Ukraine (Table 2).

Table 2. Classification of the investment climate of Ukraine's economy before investment

\begin{tabular}{ll}
\hline $\begin{array}{l}\text { General characteristics of the integral indicator of the } \\
\text { investment climate }\end{array}$ & $\begin{array}{l}\text { Evaluation } \\
\text { scale }\end{array}$ \\
\hline $\begin{array}{l}\text { Favorable investment climate - the best investment object } \\
\text { for potential investors }\end{array}$ & $8,20-10,00$ \\
$\begin{array}{l}\text { Favorable investment climate, however, with a moderate } \\
\text { risk - sufficient to invest the level of the national economy }\end{array}$ & $5,40-8,19$ \\
$\begin{array}{l}\text { Investment climate with the high risk - allocation the } \\
\text { investment capital is characterized by a high level of risk } \\
\text { and average return }\end{array}$ & $2,65-5,39$ \\
$\begin{array}{l}\text { Unfavorable investment climate with a high level of risk } \\
\text { capital - is characterized by the rate of return that is below } \\
\text { average and a high level of risk }\end{array}$ & $0-2,64$ \\
\hline
\end{tabular}

\begin{tabular}{|c|c|c|c|}
\hline Factor and its Components & Specific Gravity & Factor and its Components & Specific gravity \\
\hline \multicolumn{4}{|c|}{$\begin{array}{c}\text { where, In is the integral indicator of the investment climate of the state } \mathrm{n} \text {; xi is the estimation of the factor that affects the investment climate; } \\
\qquad y \mathrm{i} \text { is the weight factor in the integral indicator of the investment climate. } \\
\text { Political factors (specific gravity of general index- } 0,23 \text { or } 23 \% \text { ) }\end{array}$} \\
\hline General stability of political power in the state & 0,3 & The degree of public confidence in the authorities & 0,2 \\
\hline $\begin{array}{l}\text { The attitude of the authorities to investors } \\
\text { (residents and nonresidents) }\end{array}$ & 0,3 & The level of priority development regions of the state & 0,2 \\
\hline \multicolumn{4}{|c|}{ Economic factors (specific gravity of general index $-0,22$ or $22 \%$ ) } \\
\hline The level of economic activity of the population & 0,25 & $\begin{array}{l}\text { The level of state support in the form of incentives for } \\
\text { industries }\end{array}$ & 0,15 \\
\hline $\begin{array}{l}\text { The average annual inflation rate over the past } 10 \\
\text { years }\end{array}$ & 0,2 & $\begin{array}{l}\text { he development of competitiveness (global } \\
\text { competitiveness Index Global Competitiveness Index } \\
\text { (world economic forum in Davos) }\end{array}$ & 0,05 \\
\hline $\begin{array}{l}\text { The presence of foreign capital in the structure of } \\
\text { the national economy }\end{array}$ & 0,05 & The level of stability of the national currency & 0,15 \\
\hline The availability of credit in the economy & 0,1 & Unemployment & 0,05 \\
\hline $\begin{array}{l}\text { The corruption perception index (Transparency } \\
\text { International index) }\end{array}$ & 0,30 & $\begin{array}{l}\text { The index of investment freedom (Index of economic } \\
\text { freedom) }\end{array}$ & 0,20 \\
\hline $\begin{array}{l}\text { The index of freedom of trade (Index of economic } \\
\text { freedom) }\end{array}$ & 0,30 & $\begin{array}{l}\text { Index of ease of doing business (economic freedom } \\
\text { Index) }\end{array}$ & 0,20 \\
\hline \multicolumn{4}{|c|}{ Social factors (specific gravity of general index $-0,1$ or $10 \%$ ) } \\
\hline $\begin{array}{l}\text { The standard of living of the population (Index of } \\
\text { human development - HDI) }\end{array}$ & 0,3 & $\begin{array}{l}\text { The population's attitude to foreign investors and } \\
\text { foreign companies on the territory of the state }\end{array}$ & 0,15 \\
\hline
\end{tabular}

Table 3. Factor model of monitoring the investment climate in Ukraine's economy 


\begin{tabular}{|c|c|c|c|}
\hline Factor and its Components & Specific Gravity & Factor and its Components & Specific gravity \\
\hline Business acumen and ethics of business owners & 0,3 & Level of migration & 0,25 \\
\hline \multicolumn{4}{|c|}{ Technical factors (specific gravity of general index $-0,1$ or $10 \%$ ) } \\
\hline $\begin{array}{l}\text { The level of provision of natural and energy } \\
\text { resources }\end{array}$ & 0,5 & $\begin{array}{l}\text { The level of development of scientific and technical } \\
\text { capacity and infrastructure }\end{array}$ & 0,5 \\
\hline \multicolumn{4}{|c|}{ Ecological factors (specific gravity of general index $-0,02$ or $2 \%$ ) } \\
\hline The presence of well-developed transport lanes & 0,5 & Natural resources availability & 0,5 \\
\hline \multicolumn{2}{|c|}{$\begin{array}{l}\text { General integral indicator of the investment climate in the national } \\
\text { economy }\end{array}$} & $\begin{array}{l}\qquad \mathrm{xi}=\sum(\mathrm{zi} \times \mathrm{pi}) \\
\text { where } \mathrm{xi} \text { is the factor that affects the country's }\end{array}$ & Grades \\
\hline \multicolumn{2}{|l|}{ A favorable investment climate } & investment climate; & $8,20-10,0$ \\
\hline \multirow{2}{*}{\multicolumn{2}{|c|}{$\begin{array}{l}\text { A favorable investment climate, however, with moderate risk } \\
\text { Investment climate with a high risk }\end{array}$}} & zi is a point in terms of factors that affect the investment & $5,40-8,19$ \\
\hline & & climate; & $2,65-5,39$ \\
\hline \multicolumn{2}{|c|}{ Unfavorable investment climate with a high level of risk } & pi is a share component in the factor. & $1,13-2,64$ \\
\hline
\end{tabular}

As the practice of doing business in Ukraine shows, the development strategies of individual species and activities do not ensure their balance according to resources, time, and priorities. So, today, it is important to create a complex model of monitoring the investment climate in Ukraine's economy, which will ensure the integration of Ukraine in the modern global economic system as technologically developed state with an appropriate level of development of innovation policy and a clearly defined strategic objective.

The proposed monitoring provides information regarding the status of the investment climate of a state's economy in the expanded view, which allows to analyze the influence of each factor in the investment climate formation and to make an informed management decision on the adjustment of the investment policy.

The volume of inflow of foreign capital directly is affected by the factors of the state's investment climate formation. Performing a comparative analysis of factors affecting the investment climate of the state, as well as the analysis of various domestic and foreign methods of the state's investment climate assessment (International Institute for Management Development, Euromoney, the world Bank and others) identified the following factors that affect the investment climate: political, economic, legal, technological, environmental, social, and each factor is assigned a list of its components (Table 3).

\section{Results}

Using the calculated indicators of the investment climate in the economy of Ukraine by the factor model, we can determine the total integral indicator of the investment climate in the national economy. This indicator allows you to determine the level of favorable investment climate to invest, from the perspective of investment and maximum profit.

Let us calculate the factorial model of monitoring the investment climate in Ukraine's economy:

1 Political factors (the proportion of the overall index $0,23): x i=0 \times 0,3+6 \times 0,3+2 \times 0,2+4 \times 0,2=0+1,8+0,4+0,8$ $=3$ - the weight factor, which affects the investment climate of the state; In $=3 \times 0,23=0,69$ - integral indicator of the investment climate of the state political factor.

2 Economic factors (specific weight 0,22): $\mathrm{xi}=$ $2 \times 0,25+4 \times 0,15+2 \times 0,2+8 \times 0,1+8 \times 0,05+4 \times 0,15+2 \times 0,1=$
$0,5+0,6+0,4+0,8+0,4+0,6+0,2=3,5-$ the weight factor, which affects the investment climate of the state; In $=3.5$ $\mathrm{x} 0,22=0,77$ - integral indicator of the investment climate of the state economic factor.

3 Legal factors (specific gravity of 0.33): $\mathrm{xi}=$ $2 \times 0,33+0 \times 0,2+2 \times 0,3+2 \times 0,2=0,6+0+0,6+0,4=1,6-$ the weight factor, which affects the investment climate of the state; In $=1,6 \times 0,33=0,53$ - integral indicator of the investment climate of the state for legal factors.

4 Social factors (the proportion of the overall index - 0,10): $\mathrm{xi}=2 \times 0,3+4 \times 0,15+2 \times 0,25+2 \times 0,3=0,6+0,6+0,5+0,6=$ 2,3 - the weight factor, which affects the investment climate of the state; In $=2,3 \times 0,1=0,23$ - integral indicator of the investment climate of a state for social factors.

5 Technical factors (the proportion of the overall index $0,10): \mathrm{xi}=4 \times 0,5+2 \times 0,5-2+1=3$ - the weight factor, which affects the investment climate of the state; In = $3 \times 0,1=0,3$ - integral indicator of the investment climate of the state for technical factors.

6 Environmental factors (the proportion of the overall index - 0,02): $\mathrm{xi}=2 \times 0,5+2 \times 0,5=1+1=2$ - the weight factor, which affects the investment climate of the state; In $=2 \times 0,02=0,04-$ integral indicator of the investment climate of a state for environmental factors.

Overall index:

$$
\sum 0,69+0,77+0,53+0,23+0,30+0,04=2,56 \text { (grades) } .
$$

Thus, monitoring the investment climate in Ukraine's economy can be said that Ukraine's economy inherent unfavorable investment climate with a high level of risk in Ukraine. The proposed model of monitoring the investment climate of a state for the main factors influencing its formation is acceptable for use as the points awarded to each of the six factors have a great range from 0 to 10 , and the analyst can assign a score to each indicator using it for integrated assessment of management effectiveness of the investment climate. Thus, it can be stated that the development of methods of calculation of the index the investment climate is built according to the methodology of the global indices. The index has a level of detail and technical implementation, sufficient for the development and management decision-making bodies of state power of Ukraine.

The mechanism of investment climate management in Ukraine's economy provides an opportunity to assess not only 
the change in conditions for investment under certain indicators, and most importantly, in the event of adverse results, provides information about the areas and limits of change indicators (proxy variables), which will contribute to the improvement of the investment climate in the state.

The introduction factor model of monitoring the investment climate in Ukraine's economy provides an opportunity for investors to determine the most advantageous investment and for public authorities to provide adequate real investment climate management in strategically important sectors of the Ukrainian economy. Areas of development of public finance in the chaotic economy structuring are introduced early [17].

\section{Conclusions}

One of the fundamental problems of the world economy is a problem of a lack of investment resources and fight for their effective use. Because investments are always future-oriented, and therefore associated with considerable uncertainty in the economic situation and people's behavior, it leads to a high level of probability of default investment plans for objective or subjective reasons. Investing in any investment project is always risky, because the income or loss from a project is random variables, which is unknown at the time of making the investment decision. Therefore, one of the reasons that constrain the increase in external funding for the implementation of investment projects in the economy are high risks of investment of resources, which can lead to a shortfall in the planned profit or loss of investment.

Performed system monitoring shows that the involvement of foreign capital in the Ukrainian economy, keep the following conditions: not involved at the stage of implementation of the Program of attracting foreign investments into the Ukrainian economy; insufficient development of markets, and markets raw materials; low level of priority development regions; the lack of domestic innovation in priority sectors of economy of Ukraine, which would provide investor interest in investing capital; surplus controlling and overlapping functions of public authorities; the high level of unemployment in Ukraine and the prospects for further deterioration of the situation; low business acumen and ethics business owners in Ukraine; low living standards and other.

To improve the methodological provisions for the management of investment climate in the national economy have created a comprehensive factor model of monitoring the investment climate in Ukraine's economy (based on the assessment of the management factors of the investment climate and provides his assessment scale (favorable, favorable with moderate risk, high risk, adverse), which allows for comprehensive monitoring of the investment climate to promptly respond and anticipate potential threats and risks when making management decisions regarding the investment climate at the macro, meso- and micro levels. The results of the research suggest about the practical value of the results and the possibility of their implementation in the current activity.

\section{References}

[1] Kuznetsova S., "The transformation of accounting systems in the chaotic economy structuring: The synergetic approach", Risk and Decision Analysis, 2011, vol.2, no3, pp.151-160.

[2] Gavrilyuk O.V. Investment image and investment attractiveness of Ukraine / O.V. Gavrilyuk // Finance of Ukraine. - 2011. No. 2. - p. 99.

[3] Malyutin, O.K. the Concept of improving the investment climate in Ukraine / A. Malyutin // Finance of Ukraine. - 2011. No. 11. - p. 41.

[4] Rossoha V.V. Innovation paradigm management activity / V.V. Rossoha // Agroinkom. - 2007. - Issue. 5-6. - p. 59-61.

[5] Marchenko N.A. Rating of Ukraine on the level of investment attractiveness / Marchenko N.A. // Scientific Herald of CHIEU. - 2012. No. 2 (10). - p. 94-100.

[6] Kuznetsova S.A. Valuation and financial reporting of joint investment activity without creating a legal entity / Academic review, 2012, № 2 (37), - p. 82.

[7] Growth of investment attractiveness. - UCAB. - [Electronic resource] - Mode of access: http : //www.agribusiness.kiev.ua

[8] Ratings Agency Moody's [Electronic resource]: Moody’s. Mode of access: http://www.moodys.com

[9] Groht V. Warten auf den Boom: Direktinvestitionen in die osteuropäischen Beitrittsländer; Wunschdenken und Fakten / V. Groht. - Berlin: Ed. Sigma, 2010. - 240 p.

[10] Williams D. The Impact of Foreign Direct Investment on the Economic Development of Central and Eastern Europe. - 2010. - p. 54-155.

[11] Attraction of foreign direct investments into the economy of Ukraine: problems and policy activation: monograph / VS Tailors, M.I. Miller, V.B. have been Antonov; national Academy of Sciences of Ukraine, Inst. region. issled. - L., 2011. - 366 p.

[12] Musina L.A. Formation and implementation of state policy to promote the development of innovative industries and technologies / L.A. Musina // Formation of market relations in Ukraine: collection of Sciences. other - K.: NII, 2012. - № 5 (132). - p. 78-82.

[13] Official site of the Research center «Brookings Institution» [Electronic resource]. - E-mail: http://www.brookings.edu/

[14] American political journal Newsweek [Electronic resource]. Mode of access: http://www.newsweek.com/2010/08/15/interactiveinfographic -of-the-worlds-best-countries.html.

[15] Analytical report organization The Heritage Foundation [Electronic resource].-Mode of access: http://www.heritage.org/index/Ranking/Index2011Ranking.pdf.

[16] Government of the United Kingdom (2010) Eliminating World Poverty: Making Globalisation Work for the Poor. White Paper on International Development London, Parliament of the United Kingdom

[17] Kuznetsova S., Varenik V., Kohan M. (2014) Development of public finance in the chaotic economy structuring, Kyiv, ZUL. 